\title{
Evaluating municipal organic solid waste treatment technologies based on Analytic hierarchy process
}

\author{
Pengfei $\mathrm{LI}^{1, \mathrm{a}^{*} \text {, Kehong Wang }}{ }^{2, \mathrm{~b}}$ and Liao Meng ${ }^{2}$, \\ ${ }^{1}$ Harbin Institute of Technology Shenzhen Graduate School, Shenzhen Key Laboratory of Water \\ Resource Utilization and Environmental Pollution Control, Shenzhen 518055, China \\ ${ }^{2}$ Shenzhen Xiaping Solid Waste Landfill, Shenzhen 518023, China \\ a email:hitlpf1991@163.com, bemail:w.k.hong@163.com,
}

Keywords: Organic solid waste; Multi-criteria decision methods;

Analytic hierarchy process; Technology assessment;

Abstract. As municipal organic solid waste problems become increasingly serious. According to the actual engineering situation, taking into account the social, economic, technical, environmental factors and so on, which is imperative to select waste treatment technologies. In this paper, based on the relevant literature, considering the economic, technological, environmental, social indicators as the four major categories for a hierarchy construction. It uses fuzzy math method (Multi-criteria decision methods) to deal with the problem of objective factors existence, but is unable to quantify. So it is necessary to establish a complete fuzzy comprehensive evaluation model combined with the analytic hierarchy process (AHP), so that determining the weight of all indicators. It uses the AHP to make technology assessment and to evaluate organic waste treatment mode, so that decision-makers can make better choices.

\section{Introduction}

The improper treatment of organic solid waste (OSW) causes problems for health and environment, which have prompted countries to attach more importance to develop appropriate technologies for organic waste. In developed countries, some measures to be taken to reduce the amount of OSW deposited in landfills, although final process generated waste is still required. In developing countries, the situation is different, the main organic waste treatment is still a landfill ${ }^{[1]}$.

The outstanding environmental problems call for correct technical assessment and clear understanding and analysis in governmental decisions, resulting from past unreasonable decisions. Typically, we only consider the economic variables in the decision making, ignoring the other relevant variables, which are essential factors for sustainable development ${ }^{[2]}$. The organic waste treatment must be considered in the whole, and not unilaterally.

In recent years, facing the waste treatment problem, OSW processing must be evaluated, according to the actual economic, environmental, social recognition, energy recycling, etc. Efforts to improve waste treatment in China have disappointing effects because of the absence of feasibility studies, including local environment analysis, plant investment and operation costs, and public acceptance. Several studies have indicated that the use of a technique to dispose of organic waste, the economic situation in the region, and other specific conditions such as waste components may have different effects on the environment or the operating parameters of the system. Therefore, it is very necessary and convenient to use a analysis tool for the selection of waste treatment technology, which is developed based on the method of considering all aspects of the system variables.

A technology assessment (TAS) ${ }^{[3]}$,also named as the assessment of the waste treatment model, provides fair and accurate information on the environment, economy, social effects of technology applications.TAS aims to study the situation of stakeholders who have an impact because of implementation of the technology, find out a better solution. TAS identify all the possible impacts of a new technology and not just the potential impacts, including the impacts that cannot be quantified.

The TAS is a critical and essential first step for the whole system. It can identify critical factors and determine the appropriate technology for a given waste treatment problem . The number of 
variables involved in a TAS is very large, which makes it difficult for analysts to work very complicated and comprehensive information.

Multi-criteria decision methods ${ }^{[4]}$ facilitate complex decision-making in scenarios with multiple selection criteria. These methods seek to eliminate guesswork, improvisation, unexplained thought processes, and the unjustified and intuitive reasoning that sometimes accompanies most of the decisions for complex problems. The analytic hierarchy process (AHP) is one of the best known multi-criteria decision methods. So AHP can make technology assessment and evaluate organic waste treatment mode, by means of; the economic, technological, environmental, social indicators.

\section{Technologies analysis}

Analysis of technologies: Mainly to study the environment, social, economic ,technical and other important indicators to support the technical criteria weighting, and not the focus of this research. Taking into account the objectives of this study, only only highlights features of each technique, and not comprehensive comparison.

\section{Anaerobic fermentation}

Anaerobic fermentation ${ }^{[5]}$ is mainly rely on a variety of anaerobic bacteria and facultative bacteria, the function of the degradation of organic matter. Due to the complexity of anaerobic fermentation raw material source, various types of microorganisms in reaction, the process is very complicated process. Although many scholars have conducted a lot of research, but there are still many problems remain to be further discussed. Anaerobic fermentation in general can be divided into two phases of acidic and alkaline fermentation, and acid fermentation can be divided into stages of hydrolysis and acidification; Alkali fermentation can be divided into the acid fermentation attenuation phase (acetic acid production phase) and methane-producing phase, or as a methane-producing phase. This is the second anaerobic fermentation stage, the origin of the three phase and four stage theory. Same type to produce acetic acid bacteria in most cases is not very important. The most up to the present recognition is the three stage theory.

An important limitation of digesters is that the generated gas has a low calorific value (6 $\mathrm{kWh} / \mathrm{m} 3)$ compared to that landfill generated biogas $\left(43.03 \mathrm{kWh} / \mathrm{m}^{3}\right.$ or $\left.37,000 \mathrm{kcal} / \mathrm{m}^{3}\right)$. However, recent advances in cogeneration equipment have resulted in more efficient use of the generated gas, and continuing advances in fermentation techniques ensure sustained development in this field.

\section{"High pressure spray detonation + incineration/compost" integrated technology}

In high pressure spray detonation + incineration/compost treatment technology, municipal solid waste (MSW) enter the raw waste feeding system, through the magnetic separation to remove large pieces of inorganic substances and the iron metal, by conveying equipment into digestion tank, adding catalyst, to eliminate the inject steam pot, and decompression emissions after about 90 minutes of digestion reaction. In the process of digestion of organic waste can be completed about digestion degradation, sterilization, dehydration, deodorization and reduce capacity, especially part of kitchen waste. Garbage digestion wastewater of digestion, sent to sewage plant for treatment. Waste after digestion processing discharge into the row material buffer system, the process of discharge materials with the functions of pneumatic conveying, flash drying, puffing, crushing, separation effect. After digestion of garbage by dispelling material feeding to the sorting system for screening, formed after sieving and magnetic separation and undersize nutritional soil .Oversize fuel into incineration system, can be used to produce steam, heating and generating electricity. Undersize nutritional soil after compost can be used for landscaping; metals recycling; incineration slag can be used to make bricks or landfill treatment, fly ash landfill after curing processing ${ }^{[6]}$..

High pressure spray detonation solution and incineration integrated processing technology is suitable for low calorific value, high moisture content, not sorting of municipal solid waste (MSW). Native solid waste becomes $100 \%$ innocent pollution after the digestion. The waste fuel of the integrated processing, calorific value is greatly increased, which can effectively control the generation of dioxin, which are harmful gases; At the same time the burning heat energy can be used in the factory district heating or electricity, besides this process produced. Undersize nutritional soil 
can turn "waste-to-energy" by way of further the rotten fermentation, biological organic fertilizer used for landscaping, soil improvement.

\section{"Pressure extrusion + anaerobic digestion / incineration" comprehensive technology}

"Pressure extrusion + anaerobic digestion (wet) / incineration (dry) " comprehensive technology is a relatively new type of pretreatment technology, that is, the use high pressure about (600-1000 standard atmospheric pressure) to the physical separation of organic waste, through the change of pressure. It will squeeze the product consists of two parts: about 30\% moisture content of the dry composition and $90 \%$ moisture content of the wet components. Component separation by squeezing the dry and wet, dry component moisture content is low, for burning; Most of the organic material with high moisture content and wet components can apply to anaerobic digestion.

The biggest advantage " pressure extrusion + anaerobic digestion ( wet component ) / incineration (dry component ) " comprehensive technology is that the front of the press pretreatment technology to solve the problem of China's urban organic waste, which due to the characteristics, water content, the composition of the complex. Through the dry and wet pretreatment treatment, improving the resource efficiency, economic benefits.

For the back end of the anaerobic digestion technology, the principle mainly is organic waste pressure dry separation of high water cut rate, high organic matter of the slurry, in high temperature anaerobic environment, culture of bacteria, through a variety of bacterial metabolism, organic waste will be decomposed of methane, carbon dioxide and digestion residue ${ }^{[7]}$. The output of methane can be used or used as fuel. Because of the large amount of organic matter, the digestion residue can be developed to organic fertilizer.

\section{Analytic hierarchy process}

The AHP developed is a multi-criteria methodology which is established to analyze a decision problem following a hierarchical structure by Saaty ${ }^{[8]}$. Based on multiple attributes,subjective decision making process can be model used by AHP. By weighing the advantages and disadvantages of policy options under circumstances of uncertainty, decision plan is divided into various grades.

Analytic hierarchy process has been widely used in different areas of the complex decision-making and evaluation, including the trade-off between multiple targets.Using the AHP, from the different perspective of fields, is evaluated in a large number of instances.For solid waste management, some studies have been developed by using AHP as a tool.However, their method to evaluate waste management, not technology assessment.

For a single assessment maker, The application of AHP to solve a technology assessment problem involves four main steps. The first step is to discompose the assessment problem into a hierarchy map where the attributes and plans are present as inter-related elements ${ }^{[9]}$.

The second step includes the paired comparison between elements, based on the weighted,and generated the input data.Compared with the 1-(n-1) element, $\mathrm{n}$ is the size of the matrix. In this process, itis possible to know which options and attributes are necessary. The resulting data is mapped to its final value based on the hierarchy structure. Assessment elements in hierarchical map are used to develop a survey questionnaire. According to the TAS plans, each decision attribute is compared.

The third step is based on pairs of use as input to create a comparison matrix, it follows the four main validity axiom for the matrix.If matrix $\mathrm{A}$ has no inconsistencies, solving the equation $\mathrm{Aw}=$ $7 \mathrm{max}$, the relative weights could be found, where $\urcorner$ is the only nonzero eigenvalue of matrix A.

Through all the comparison, the consistency index (CI) is largest eigenvalue (max) for an $\mathrm{n} \times \mathrm{n}$ comparison matrix , where $C I$ can be calculated with $C I=(\max -n /(n-1))$. Judgment consistency ratio $(\mathrm{CR})$ can be calculated with $\mathrm{CI}$ and the randomly index $(\mathrm{RI}), \mathrm{CR}=\mathrm{CI} / \mathrm{RI}$, where $\mathrm{RI}$ values can be . CR valid value does not exceed 0.10 or a $10 \%$.If exceed, the judgment matrix is inconsistent. To obtain a consistency matrix, judgments should be carefully reviewed and improved ${ }^{[10]}$.

The fourth steps involves to estimate the final weight rating based on actual attributes. By comparing the final weight rating value, it will be able to come to the best evaluation plan. 
AHP is a case for multi-objective decision method, is also one of the best technology for the sustainable development decision-making, because of the AHP can be easily and effectively determine the selection criteria, compared with other methods, weighted and classified and analyzed. AHP can assess subjective and objective measures, which provides a useful mechanism for checking the evaluation measures of correlation and alternatives. In general, there are two methods, using AHP to gather the group preferences.The first one is the geometric average method (GMM), which is used as a paired comparison matrix elements, then priority and calculation. The second one method is weighted arithmetic mean method (WAMM). Either GMM or WAMM can be used to estimate the resulting priorities for the organic waste technology assessment.

Municipal decision-makers need a technology assessment-making model to aid them in selecting new technologies. Because there is no methodology available for similar situations in public documents. The objective for this study was to develop a TAS using the AHP to determine most suitable OSW treatment for most of cities .

\section{Technology assessment}

According to the actual appropriate situation, taking into account the economic, technical, environmental, social factors and so on, it is imperative to select waste treatment methods. Based on the relevant literature, considering the economic, technological, environmental, social indicators as the four major categories for a hierarchy construction, as is shown in Table 1.Comprehensive survey of the process, from the perspective of different factors, anaerobic fermentation, high pressure spray detonation+incineration/compost,pressure extrusion + anaerobic digestion / incineration, can clearly make a scientific summary. 
Table 1 Summary of observations on the solid waste treatment technologies

\begin{tabular}{|c|c|c|c|}
\hline indicators & $\begin{array}{l}\text { Anaerobic } \\
\text { fermentation }\end{array}$ & $\begin{array}{c}\text { High pressure spray } \\
\text { detonation+incineration/ } \\
\text { compost }\end{array}$ & $\begin{array}{l}\text { Pressure extrusion + } \\
\text { anaerobic digestion / } \\
\text { incineration }\end{array}$ \\
\hline $\begin{array}{l}\text { Employment } \\
\text { Level }\end{array}$ & $\begin{array}{l}\text { Medium; low } \\
\text { academic level } \\
\text { qualifications }\end{array}$ & $\begin{array}{c}\text { High; personnel with high } \\
\text { academic } \\
\text { Level qualifications }\end{array}$ & $\begin{array}{l}\text { Low; only personnel } \\
\text { with high academic } \\
\text { level qualifications }\end{array}$ \\
\hline People approval & High $(94 \%)$ & Medium $(88 \%)$ & Low $(53 \%)$ \\
\hline Soil pollution & Low & Low & Medium \\
\hline Air pollution & $\begin{array}{l}\text { Low; advanced } \\
\text { pollution control not } \\
\text { required }\end{array}$ & $\begin{array}{c}\text { Medium; there are odor } \\
\text { emissions }\end{array}$ & $\begin{array}{l}\text { High, requires strict } \\
\text { pollution control }\end{array}$ \\
\hline Water pollution & $\begin{array}{l}\text { Medium; possible } \\
\text { effluent discharges }\end{array}$ & $\begin{array}{l}\text { Low; water used only for } \\
\text { synthesis gas cooling }\end{array}$ & High; Slurry pollution \\
\hline $\begin{array}{c}\text { Approval of } \\
\text { decision-makers }\end{array}$ & Medium & High & High \\
\hline $\begin{array}{l}\text { Regulation and } \\
\text { supervision }\end{array}$ & $\begin{array}{l}\text { High; economic } \\
\text { incentives for } \\
\text { installation }\end{array}$ & $\begin{array}{c}\text { Medium; no incentives for } \\
\text { installation and no } \\
\text { legislative restrictions }\end{array}$ & $\begin{array}{l}\text { Low; no unified } \\
\text { standard }\end{array}$ \\
\hline $\begin{array}{l}\text { Construction } \\
\text { investment }\end{array}$ & $\begin{array}{l}\text { Low; local } \\
\text { construction }\end{array}$ & $\begin{array}{l}\text { High; requires import of } \\
\text { technology }\end{array}$ & $\begin{array}{l}\text { High; requires import } \\
\text { of technology and spare } \\
\text { parts }\end{array}$ \\
\hline Operating costs & $\begin{array}{l}\text { Low; nationally } \\
\text { available spare parts } \\
\text { and local labor }\end{array}$ & $\begin{array}{l}\text { High; the spares are } \\
\text { expensive }\end{array}$ & $\begin{array}{l}\text { High; the spares are } \\
\text { expensive, highly } \\
\text { skilled work force } \\
\text { required }\end{array}$ \\
\hline $\begin{array}{l}\text { Market for } \\
\text { products }\end{array}$ & $\begin{array}{l}\text { Medium; Biogas and } \\
\text { Fertilizer market }\end{array}$ & $\begin{array}{l}\text { High; Fertilizer market and } \\
\text { energy and electricity }\end{array}$ & $\begin{array}{l}\text { High; Biogas and } \\
\text { electricity }\end{array}$ \\
\hline $\begin{array}{l}\text { Amount of } \\
\text { treatment }\end{array}$ & $\begin{array}{l}\text { Medium; } 30 \% \text { the } \\
\text { waste generated can be } \\
\text { processed }\end{array}$ & $\begin{array}{l}\text { High; about } 90 \% \text { the waste } \\
\text { generated can be processed }\end{array}$ & $\begin{array}{l}\text { High; } 80 \% \text { waste } \\
\text { generated can be } \\
\text { processed }\end{array}$ \\
\hline $\begin{array}{c}\text { Waste } \\
\text { composition }\end{array}$ & Organic matter & $\begin{array}{c}\text { Organic matter and } \\
\text { high moisture content }\end{array}$ & $\begin{array}{c}\text { Organic matter and } \\
\text { high moisture content }\end{array}$ \\
\hline
\end{tabular}

\section{Conclusion}

Using AHP method in fuzzy mathematics to evaluate the organic waste treatment model, including anaerobic fermentation, "high pressure spray detonation+ incineration/compost" integrated technology, "pressure extrusion + anaerobic digestion / incineration" comprehensive technology and so on. Comprehensively describe the objective indicators for the technology, fully considering the economic, technological, environmental, social indicators as the four major categories for a hierarchy construction, so that determining the weight of all indicators. It using the AHP to make technology assessment and to further evaluate organic waste treatment mode. Municipal decision-makers will achieve a technology assessment model to aid them in selecting new organic waste treatment technologies. The objective for this study was to develop a technology assessment using the AHP to determine most suitable OSW treatment for most of cities.

\section{Acknowledgements}

This work is supported by research project granted by Shenzhen Urban Management Bureau (Grant No. 2014. 17). 


\section{References}

[1]Buenrostro, O., \& Bocco, G. (2003). Solid waste management in municipalities in Mexico: goals and perspectives. Resources, Conservation and Recycling, 39(3), $251-263$.

[2]Daven, J. I.,\&Klein, R. N. (2008). Progress in waste management research. New York: Nova Science Publishers Inc.

[3]Dickey, J., Glancy, D., \& Jennelle, E. (1973). Technology assessment: its application to the solid waste management programs of Urban governments. Lexington: Lexington Books.

[4]Bellman, R., Zadeh, L. A. Decision-making in a fuzzy environment. Management Science, 1970, 17(B): 141-164

[5]BOLZONELLAD, INNOCENTIL, PAVAN P, et . Semi-dry thermophilic anaerobic digestion of the organic fraction of municipal solid waste: focus on the start - up phase[J]. Bioresource Technology, 2003(86): 123-129.

[6]He W, Li G, Kong L, et al. Application of hydrothermal reaction in resource recovery of organic wastes[J]. Resources, Conservation and Recycling, 2008, 52(5): 691-699.

[7]Arsova L. Anaerobic digestion of food waste: Current status, problems and an alternative product [EB/OL]. http://www.seas.columbia.edu/earth/wtert/sofos/arsova_thesis.pdf.

[8]Francisco Contrerasa, Keisuke Hanakia, Toshiya Aramakia, Stephen Connorsb Application of analytical hierarchy process to analyze stakeholders preferences for municipal solid waste management plans, Boston, USA Resources, Conservation and Recycling 52 (2008) 979 - 991

[9]Al-Harbi K. Application of the AHP in project management. Int J Project Manage 2001;19(1):19 $-27$.

[10]Castells, X. E. (2000). Reciclaje deresiduos industriales. Madrid: Ediciones Díaz de Santos. 